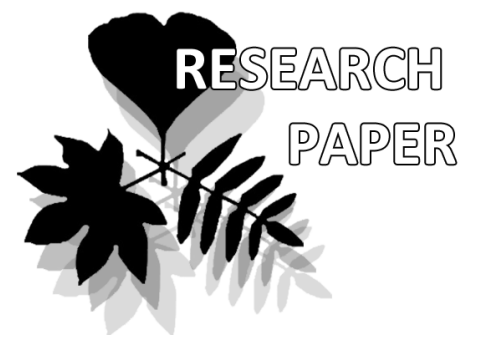

Eckart Schrank

e-mail: e.schrank@tu-berlin.de

Institut für Angewandte

Geowissenschaften, Technische Universität Berlin, EB10, Strasse des 17. Juni 145, D-10623 Berlin, Germany

Manuscript received: 04.08.2015 Review completed: 22.09.2015 Accepted for publication: 23.09.2015 Published online: 26.09.2015

\section{Variability and Morphology of Some Pteridophytic Spores from the Early Cretaceous (Albian) of the Negev, Israel}

\author{
Eckart Schrank
}

\begin{abstract}
A B S T R A C T
An independently dated locality at Makhtesh Qatan, northern Negev, has yielded rich paleobotanical and palynological material of Albian age. The palynoflora is dominated by pteridophytic spores, mainly trilete, laevigate forms, while gymnospermous and angiospermous pollen grains occur as subordinate elements. In this paper emphasis is placed on some pteridophytic spores which are illustrated using light microscopy (LM) and scanning electron microscopy (SEM). The following laevigate spores are discussed: Cibotiumspora jurienensis, Dictyophyllidites harrisii, Dictyophyllidites cf. harrisii and Dictyophyllidites mesozoicus. Apiculate and cicatricose forms include Concavissimisporites punctatus, Concavissimisporites cf. variverrucatus, Osmundacidites sp. 1, Gemmatriletes clavatus and Cicatricosisporites avnimelecbi. Most pteridophytic spores are stratigraphically long-ranging and have a wide distribution. However, Cicatricosisporites avnimelechi is generally not younger than Albian and mainly restricted to the African-South American Microfloral Province.

K e y w o r d s : pteridophytic spores, Cretaceous, Albian, Negev, Israel
\end{abstract}

\section{P E 3 Ю M E}

Шранк Э. Вариабельность и морфология некоторых папоротниковидных спор из раннего мема (альб) пустыни Негев, Израиль. Местонахождение ископаемых остатков Махтеш Катан в Северном Негеве, возраст которого однозначно определен рядом экспертов, АаАо богатый палеоботанический и палинологический материал альббского возраста. В палинофморе преобладают споры папоротниковидных, главным образом, трилетных гладких форм, в то время как пыльца голосеменных и покрытосеменных уступает по количеству. В статье уделяется внимание спорам некоторых папоротниковидных, которые изучены с помощью световой и сканирующей эмектронной микроскопии. ОбсужАаются глаАкие споры следующих видов: Cibotiumspora jurienensis, Dictyophyllidites harrisii, Dictyophyllidites cf. harrisii и Dictyophyllidites mesozoicus. Угловатые и цикадовиАные формы характерны Аля Concavissimisporites punctatus, Concavissimisporites $\mathrm{cf}$. variverrucatus, Osmundacidites sp. 1, Gemmatriletes clavatus и Cicatricosisporites avnimelechi. Большинство спор видов папоротниковидных имеют широкий стратиграфический спектр и широко распространены. Тем не менее, Cicatricosisporites avnimelechi, как правимо, не моложе альба, а его распространение, в основном, ограничивается африкано-южноамериканской микрофмористической провинцией.

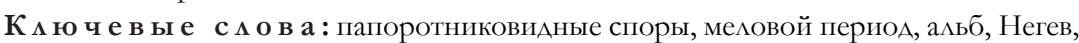
Израиль

Переведено редкомлегией

\section{INTRODUCTION}

The present paper represents a contribution to the Early Cretaceous palynology of a unique locality in the Negev Desert in southern Israel. Pre-Quaternary palynomorph assemblages in general and Cretaceous assemblages in particular have rarely survived in surface exposures under the harsh arid conditions of the Negev. Most previous paleopalynological studies in the deserts of Israel and surrounding areas have therefore relied on subsurface material derived from wells drilled for the exploration of water, hydrocarbons and other deposits (e.g. Horowitz 1970, Brenner 1974, Brenner \& Bickoff 1992, Weissbrod et al. 1994).
The only surface locality in the Negev Desert that yielded plant macrofossils associated with rich palynofloras is the fossil plant-bearing bed IQ1 of Krassilov \& Schrank (2011). This bed represents a shale horizon intercalated in the middle part of about $160 \mathrm{~m}$ of predominantly fluvial sandstones of the Upper Hatira Formation in the Makhtesh Qatan structure, a breached anticline in the northern Negev, about $53 \mathrm{~km}$ south-east of Beersheba (see map in Krassilov \& Schrank 2011 and Schrank 2013).

The Upper Hatira Formation is overlain by the carbonates of the Hazera (Hevyon) Formation. The lower part of the Hazera Formation has yielded a marine fauna inclu- 
ding the late Albian ammonite Hypengonoceras at Makhtesh Ramon (Lewy 1981). Ammonites found at Makhtesh Hatira (Knemiceras) point to an Albian age of the fossil plant-bearing bed IQ1 and of the two overlyinng beds IQ2 and IQ3 (see Krassilov \& Schrank 2011 and references therein) which is consistent with palaeobotanical and palynological age interpretations.

Preliminary reports on certain aspects of the macroflora (IQ1-3) and the palynoflora (IQ1 only) have been published by Krassilov \& Schrank (2011) and Schrank (2013). Sporomorph assemblages from the locality IQ1 were found to be strongly dominated by psilate, trilete spores including Diytyophyllidites, Deltoidospora, Triplanosporites, Cyathidites, Concavisporites, Cibotiumspora and others. Other pteridophytic spores such as Concavissimisporites, Gemmatriletes, Cicatricosisporites, Verrucosisporites and Sestrosporites are less abundant. Gymnosperm pollen is represented by inaperturate forms including Araucariacites, Balmeiopsis, Callialasporites and related types. Subordinate members of the gymnospermous palynoflora include Classopollis, Eucommïidites and Ephedripites while angiosperm pollen represent a minor element of the palynoflora, for example Clavatipollenites, Pennipollis, Retimonocolpites, Tricolpites, Rousea and Walkeripollis. The latter form, a monoporate tetrad pollen of winteraceous affinity has been re-interpreted as a new genus and species named Qatanipollis valentini in honour of Valentin Krassilov (Schrank 2013).

The main purpose of the present paper is to describe and illustrate some pteridophytic spores with emphasis on the characteristic and widespread Cibotiumspora jurienensis (Balme) Filatoff 1975 using light and scanning electron microscopy. Previously the morphology and variability of this species has been documented from places as far apart as Israel (Horowitz 1970), Canada (Singh 1971), Australia (Filatoff 1975) and China (Song et al. 2000).

\section{SYSTEMATIC PALYNOLOGY}

\section{Laevigate spores}

Cibotiumspora jurienensis (Balme 1957) Filatoff 1975 sensu lato. Plate 1, figs. 1-18

1957 Concavisporites jurienensis - Balme, p. 20, pl. 2, figs. $30-31$;

1970 Concavisporites jurienensis - Horowitz, p. 163, pl. 1, figs. 11-12 (13-14?);

1975 Cibotiumspora jurienensis - Filatoff, p. 61, pl. 10, figs. 8-13;

1976 Concavisporites sinuatus - Saad and Ghazaly, p. 416, pl. 2, fig. 4 (slightly convex to concave sides; kyrtome, straight folds across apices = type ND97);

1980 Deltoidospora junctum - Kumar, p. 435, pl. 1, fig. 7;

1981 Concavisporites jurienensis - Abdelmalik et al., fig. 5/17 (straight sides, kyrtome, obtusi apparatus);

1985 Concavisporites jurienensis - Thusu and Van der Eem, pl. 54, fig. 1 (52 $\mu \mathrm{m}$, straight to slightly concave sides, kyrtome and obtusi apparatus present $=$ type ND97= Plate 1, fig. 6);

1985 Gleicheniidites apilobatus - Batten and Uwins, pl. 66, fig. 9 (Burger, 1966 regards G. apilobatus Brenner as synonym of Concavisporites jurienensis);

1986 Concavisporites sinuatus - Sultan, p. 58, pl. 1, fig. 9 (36 $\mu \mathrm{m}$, triangular outline, kyrtome and obtusi apparatus present = type ND97);

?1987 Obtusisporis juriensis [sic] - Srivastava, p. 28, pl. 8, figs. 6-7;

1988 Cibotiumspora jurienensis - Backhouse, p. 54, pl. 3, figs. 2 (holotype refigured) and 3? (a small specimen without kyrtome);

1988 Concavisporites jurienensis - Pons, p. 79, pl. 17, figs. 3, 5 (specimens with concave and convex sides, kyrtome, obtusi apparatus);

1995 Cibotiumspora jurienensis - Schrank and Ibrahim, pl. 5, fig. 13 (25 $\mu \mathrm{m}$, small type ND97);

cf. 1995 Obtusisporis divisitorus - Kedves, p. 33, pl. 3, figs. 8, 9; 2000 Cibotiumspora jurienensis - Song et al., p. 38, pl. 7, figs. 15, 19, 20, 35;

2001 Cibotiumspora jurienensis - Ibrahim et al., p. 276, 279, fig. 8 e (slightly convex to straight sides, kyrtome, obtusi apparatus);

2007 Cibotiumspora jurienensis - Mahmoud and Deaf, pl. 1, fig. c $(40 \mu \mathrm{m}$, straight to slightly concave sides, kyrtome and obtusi apparatus present, well preserved = type ND97);

2010 Cibotiumspora jurienensis - El Beialy et al., fig. 3 D (type ND97);

2011 Cibotiumspora jurienensis - Krassilov and Schrank, p. 22, fig. 7C.

Remarks: The list of synonyms above shows only a few examples of the many citations of this widespread species in the literature. In Palynodata the combination Concavisporites jurienensis is most common with 164 entries, Cibotiumspora jurienensis comes second with 93 entries (both Palynodata 2005), and the name Obtusisporis juriensis based on Srivastava (1987) has only two entries. The presumed total age range of these taxa is Middle Triassic to Miocene. An alleged Middle Devonian to Early Carboniferous age for Concavisporites jurienensis in Palynodata 2005 is based on Von der Brelie (1964) who studied palynofloras from a crevice in Middle Devonian limestones filled with Early Cretaceous (possibly Aptian-Albian) clay and fossils.

Balme (1957, p. 20) provided the following description of his new species Concavisporites jurienensis:

"Amb triangular, sides usually straight, sometimes slightly concave or convex. Trilete, laesurae extending to the periphery, bordered by strong arcuate folds or thickenings, concave towards the proximal pole, joined at the ends of the three laesurae. Arcuate thickenings sometimes extended as sharply angular auriculae at each of the apices. Exine 1-2 $\mu \mathrm{m}$ thick, smooth."

The spelling "Concavisporites juriensis" as used in the explanation of the plate 2 (Balme 1957, p. 3 ) is regarded as an orthographic error.

Based on material from the Upper Triassic-Jurassic of Israel, Horowitz (1970) formulated a modified description: "Spore trilete, laesurae reaching equator, flanked by a broad, distinct margo. Commissures raised. Equatorial contour triangular, sides straight to slightly concave, apices somewhat pointed. Exine 1.5-3 $\mu \mathrm{m}$ thick, smooth. Margo forms typical concave ridges. Apical auriculae sometimes present."

In contrast to earlier authors Burger (1966) and Singh (1971) restricted the species to relatively small forms with distinctly concave sides (cf. Pl. 1, figs. 17-18, present material). Singh (1971) used this feature together with the presence of arcuate folds in the proximal interradial regions (kyrtoms) to distinguish Concavisporites jurienensis from Deltoidospora juncta (Kara-Murza) Singh.

Filatoff (1975) transferred the species Concavisporites jurienensis to the genus Cibotiumspora and modified the description as follows: 
"Amb triangular, sides concave, rarely straight to slightly convex, apices rounded to somewhat pointed. Trilete, laesurae sinuous, $1 \mu \mathrm{m}$ high, $1 \mu \mathrm{m}$ wide, extend to spore margin, and may be bordered by strong arcuate folds (kyrtome). Exine 1-2 $\mu \mathrm{m}$ thick, scabrate to punctate. Distal face with a straight fold across at least one, generally all apices."

Filatoff (1975) expanded the concept of the species by including forms without a kyrtome and with straight "obtusi apparatus" (distal folds, see below) (Filatoff 1975, pl. 10, figs. 9, 11).

The holotype of Concavisporites jurienensis (see Balme 1957, pl. 2, fig. 30; Backhouse 1988, pl. 3, fig. 2) is a specimen with straight sides. One of the three apices (corners) is slightly protruding. The kyrtomes are indistinct and arcuate to irregularly shaped. The laesurae are more or less straight and extend to the margin of the corners. The "obtusi apparatus" (distal folds, see below) is arcuate where the corner is protruding, otherwise it is weakly arcuate to straight.

Among the specimens found in the material from Makhtesh Qatan some conform well with the holotype, namely Plate 1, figs. 1, 3-5, 13-16, others fit into the expanded concept of this species proposed by Filatoff (1975).

In summary it can be said that this species is characterized by a laesura with more or less strong arcuate folds (kyrtomes) combined with distal folds running across one or all three apices ("Obtusiapparat" or "obtusi apparatus", Krutzsch 1959, Kedves \& Simoncsics 1964). This is a highly variable species or group of intergrading taxa with respect to outline (sides are straight to concave); arcuate folds accompanying the laesura (kyrtomes) may be well developed or missing which is also true for the obtusi apparatus.

Botanical affinities: Pteridophyta, incertae sedis (Singh 1971), listed as Cyatheaceae/Dicksoniaceae-type spores (Filatoff 1975); Gleicheniaceae? (Pons 1988).

Selected previous records: Jurassic of Western Australia (Balme 1957, Filatoff 1975); pollenzone R to Z (late Kimmeridgian to Valanginian), the Netherlands (Burger 1966); Upper Triassic to Jurassic of the northern Negev, Israel (Horowitz 1970); Jurassic and Lower Cretaceous throughout the world (Filatoff 1975 and references therein); Kimmeridge-Purbeck, central Egypt (Saad \& Ghazaly 1976 as Concavisporites sinuatus); Maastrichtian, Texas (Kumar 1980 as Deltoidospora junctum); Neocomian, Betty well, northwestern Desert, Egypt (Abdelmalik et al. 1981); Lower Cretaceous, Ukraine (Voronova 1984); Neocomian to Albian, Libya (Thusu \& Van der Eem 1985); Aptian - Albian of Libya (Batten \& Uwins 1985 as Gleicheniidites apilobatus); Lower Cretaceous, Nile Delta region (Sultan 1986 as Concavisporites sinuatus); lower Sinemurian, Germany (Srivastava 1987); Aptian, Colombia (Pons 1988); Kimmeridgian to Aptian, Western Australia (Backhouse 1988): CenomanianLower Santonian, Egypt (Schrank \& Ibrahim 1995); Early Jurassic to Albian, Eastern Desert, Egypt (Ibrahim et al. 2001); Triassic to Early Cretaceous, China (Song et al. 2000, Palynodata 2005); Berriasian to lower Cenomanian, Northern Egypt (Mahmoud and Deaf 2007); middle Albian/middle Cenomanian, Sinai, Egypt (El Beialy et al. 2010).

Cibotiumspora jurienensis (Balme) Filatoff sensu Singh
1971. Pl 1, figs. 17-18

Remarks: Relatively small representatives $(35 \mu \mathrm{m})$ of the Cibotiumspora jurienensis group with concave sides, obtusi apparatus and indistinct kyrtome occur as rare elements in the present material.

They have been reported from the Late Jurassic and Early Cretaceous of various parts of the world including Western Canada (Singh 1971), and they are comparable with Obtusisporis undulus (Kedves and Simoncsics) Kedves 1995 subfsp. africanus Kedves 1995 described from the Cretaceous of Egypt (Kedves 1995).

Dictyophyllidites harrisii Couper 1958 (= D. harrisii sensu Ravn 1995). Pl. 2, fig. 2

Remarks: As noted previously the arcuate thickenings (kyrtomes) of this species are highly variable (Schrank 1994). Specimens with indistinct kyrtomes appear transitional to forms like Deltoidospora. The size range of specimens in the present material is approximately between 43 and $52 \mu \mathrm{m}$ which is within the range of specimens from the British Jurassic (36 to $56 \mu \mathrm{m}$, Couper 1958).

Botanical affinities: Dictyophyllidites was assigned to the family Cheiropleuriaceae (Singh 1971) or Matoniaceae/ Weichseliaceae (Schrank 1994 and references therein). Some specimens conform to the spores of Weichselia reticulata from the Albian of Spain as illustrated by Diez et al. (2005).

Selected previous records: Worldwide, Jurassic, Cretaceous (Srivastava 1977); Albian, USA (Ravn 1995); Triassic-Cretaceous, nearly cosmopolitan (Schrank 1994 and references therein). In the Danian of Argentina Dictyophyllidites harrisii is interpreted as part of a hygrophile community of ferns and other pteridodphytes (Volkheimer et al. 2007). It has 398 taxon entries (Triassic to Tertiary) in Palynodata 2005.

Dictyophyllidites cf. harrisii Couper sensu Volkheimer et al. 2007. Pl. 2, fig. 1

Dictyophyllidites mesozoicus (Döring 1965) Kedves 1995. Pl. 2, figs. 10-11

1965 Toroisporis (Toroisporis) mesozoicus n. fsp. - Döring, p. 25 , pl. 7, figs. 1-3.

1995 Dictyophyllidites mesozoicus n. comb.- Kedves, p. 23.

Selected previous records: Wealden A, B and upper Wealden, East Germany (Döring 1965).

Palynodata 2005 record 1 entry for Dictyophyllidites mesozoicus and 14 entries for Toroisporis mesozoicus with a total stratigraphic range from the Hettangian to Maastrichtian, mainly of Europe.

\section{Dictyophyllidites sp.}

Remarks: Dictyophyllidites sp. (cf. Deltoidospora psilostoma sensu Krassilov \& Schrank 2011) agrees well with in situ spores of Weichselia negevensis Silantieva and Krassilov as illustrated in Krassilov \& Schrank (2011, fig. 3F).

\section{Apiculate (granulate) spores}

Concavissimisporites punctatus (Delcourt and Sprumount 1955) Brenner 1963. Plate 2, figs. 3-5

Remarks: This species is distinguished from Concavissimisporites variverrucatus by its very shallow microgranulate to punctate sculpture. 
Botanical affinity of Concavissimisporites: Cyathea, Dicksonia, Lygodium (Dettmann 1963 and references therein).

Selected previous records: Berriasian to Albian, North America, Europe, Australia, Russia (Singh 1971, Srivastava 1977 and references therein); Aptian-Albian, Brazil (Pons et al. 1996). Number of taxon entries in Palynodata 2005: 226 (Early Triassic to Early Oligocene).

Concavissimisporites cf. variverrucatus (Couper) Brenner 1963. Plate 2, figs. 6-7

Selected previous records: Mesozoic, Israel (Horowitz 1970); Bajocian to Albian, North America; Bajocian to Barremian, England (Singh 1971 and references therein); Albian, Oklahoma (Wingate 1980); Lower Cretaceous of Argentina (as Concavissimisporites sp. in Mego \& Pramparo 2013). Number of taxon entries in Palynodata 2005: 225 (Middle Triassic to Maastrichtian).

Gemmatriletes clavatus Brenner 1968 sensu Krassilov \& Schrank 2011. Plate 2, figs. 12-13

Remarks: This spore species is highly variable with respect to equatorial outline (round, elliptical, triangular) and size and density of its sculpture which is formed by a dense cover of clavate elements. These are usually reduced in the immediate surrounding of the Y mark. Similar or identical forms are also known under the name Clavatisporites clarus Kedves and Simoncsics. In the Palynodata 2005 Version Gemmatriletes clavatus and Clavatisporites clarus have 17 and 14 taxon entries, respectively and stratigraphic ranges from Hauterivian to Maastrichtian (the former) and Middle Jurassic to Aptian (the latter).

Botanical affinity: Selaginella (Shaw \& Huang 1994, for Gemmatriletes speciosus).

Selected previous records: Albian and Cenomanian of Peru (Brenner 1968 ) and North America (Singh 1983 and references therein); Hauterivian to early Cenomanian and Albian of Israel (Brenner 1974, Krassilov \& Schrank 2011).

\section{Osmundacidites sp. 1. Plate 2, figs. 8-9}

Remarks: This species is closely related to Osmundacidites wellmanii, a widespread taxon covered by 834 taxon entries (Early Permian to Middle Miocene) in Palynodata 2005. Osmundacidites sp. 1 is distinguished from Osmundacidites wellmanii Couper as described by Couper (1958) and Dettmann (1963) by its smaller size [33 (36.7) $40 \mu \mathrm{m}$ vs 36 (51) 67 $\mu \mathrm{m}$, Dettmann 1963] shorter laesurae and the details of its sculpture (visible under SEM). The sculpture consists of a dense cover of shallow confluent, granulate to rugulate elements which encircle micro-perforations $(<0.5 \mu \mathrm{m}$ dia- meter). Such perforations are not known in Osmundacidites wellmanii. However, the surface of Osmundacidites cf. wellmanii sensu Kedves (1995) was described as punctate or finely granulate based on light microscopy only.

Botanical affinity of Osmundacidites: Osmundaceae (Couper 1958, Dettmann 1963).

\section{Cicatricose spores}

Cicatricose spores are characterized by the presence of ridges, ribs or muri separated from each other by furrows. In the Albian of Makhtesh Qatan these forms are represented by the genera Appendicisporites and Cicatricosisporites. A single example of the former has been found, but will not be discussed in the present paper. Cicatricosisporites is mainly represented by two species with circular to sub-circular equatorial outline, namely Cicatricosisporites avnimelechi Horowitz and C. nuni Horowitz. The former has yielded a well preserved specimen under SEM.

Cicatricosisporites avnimelechi Horowitz 1970. Plate 2, fig. 14

1970 Cicatricosisporites avnimelechi-Horowitz, p. 104, pl. 2, figs. 4-6.

Remarks: This species is distinguished from C. nuni by its smaller size and coarser ribs (see Horowitz 1970). It is usually not younger than Albian and is thus among the pteridophytic spores which potentially have some palynostratigraphic significance.

Botanical affinity of Cicatricosisporites: Schizaeaceae (Dettmann 1963).

Selected previous records: Upper Jurassic (contaminated?)-Lower Cretaceous, Israel (Horowitz 1970 and footnote in Herngreen 1973); Lower Cretaceous, Syria (Kotova 1990), Aptian-Albian of Egypt (Schrank \& Ibrahim 1995 as Cicatricosisporites orbiculatus) and Brazil (Pons et al. 1996, Regali 1989). Palynodata 2005 records 11 taxon entries and a stratigraphic range from Bathonian to Albian.

\section{ACKNOWLE D G E M E N S}

Financial support for this work came from the GermanIsraeli Foundation for Scientific Research and Development (GIF), Grant no. I-888-159.8/2005. This project was initiated by Professor Valentin Krassilov who also guided field work in Israel. Palynological processing and SEM work was done by Alexander Hartwig and Jörg Nissen (TU Berlin), respectively. I am grateful to Professor Wilhelm Dominik for permission to use facilities at TU Berlin, and I thank the Guest editor Dr. Sophia Barinova for inviting me to contribute to this volume.

Plate 1. Variation and different states of preservation in the widespread Mesozoic spore Cibotiumspora jurienensis (Balme) Filatoff sensu lato based on material recovered from surface exposures of Albian age at Makhtesh Qatan (plant-bearing bed IQ1 of Krassilov \& Schrank 2011), Northern Negev, Israel. Scale bar on all figures corresponds to $10 \mu \mathrm{m}$. Typical specimens are figs. 1, 3-5, 11-16. All specimens illustrated on Plates 1 and 2 are housed at Technical University of Berlin (Technische Universität Berlin).

Fig. 1 - Cibotiumspora jurienensis, SEM photo no. CK42, slide 330-BNA2; Fig. 2 - cf. Cibotiumspora jurienensis, SEM photo no. CJ23, slide 327-BMX3; Figs. 3-5 - C. jurienensis, same specimen as Fig. 1, LM photos no. NH57-59 from high to low focus, slide 330BNA2, England Finder reference (EF) J36/4. Cf. Filatoff, 1975, pl. 10, fig. 10. Internal and external perforations of kyrtome are regarded as preservational artefacts; Fig. 6 - C. jurienensis, LM photo ND97, slide 329-BMZ3, EF W30. Specimen is triangular with straight sides, indistinct kyrtome, three distal folds crossing at right angles the rays of the trilete mark ("Obtusiapparat" or "obtusi apparatus", Krutzsch, 1959; Kedves \& Simoncsics, 1964). Cf. C. jurienensis in Schrank \& Ibrahim 1995, pl. 5, fig. 13 and Concavisporites sinuatus sensu Saad \& Ghazaly 1976, pl. 2, fig. 4; Fig. 7 - C. jurienensis, LM photo NE67, slide 330-BNA1, EF E45/3. Specimen compares well with fig. 6, but lacks the kyrtome (cf. Filatoff 1975, pl. 10, figs. 9 and 11), possibly as a result of natural 

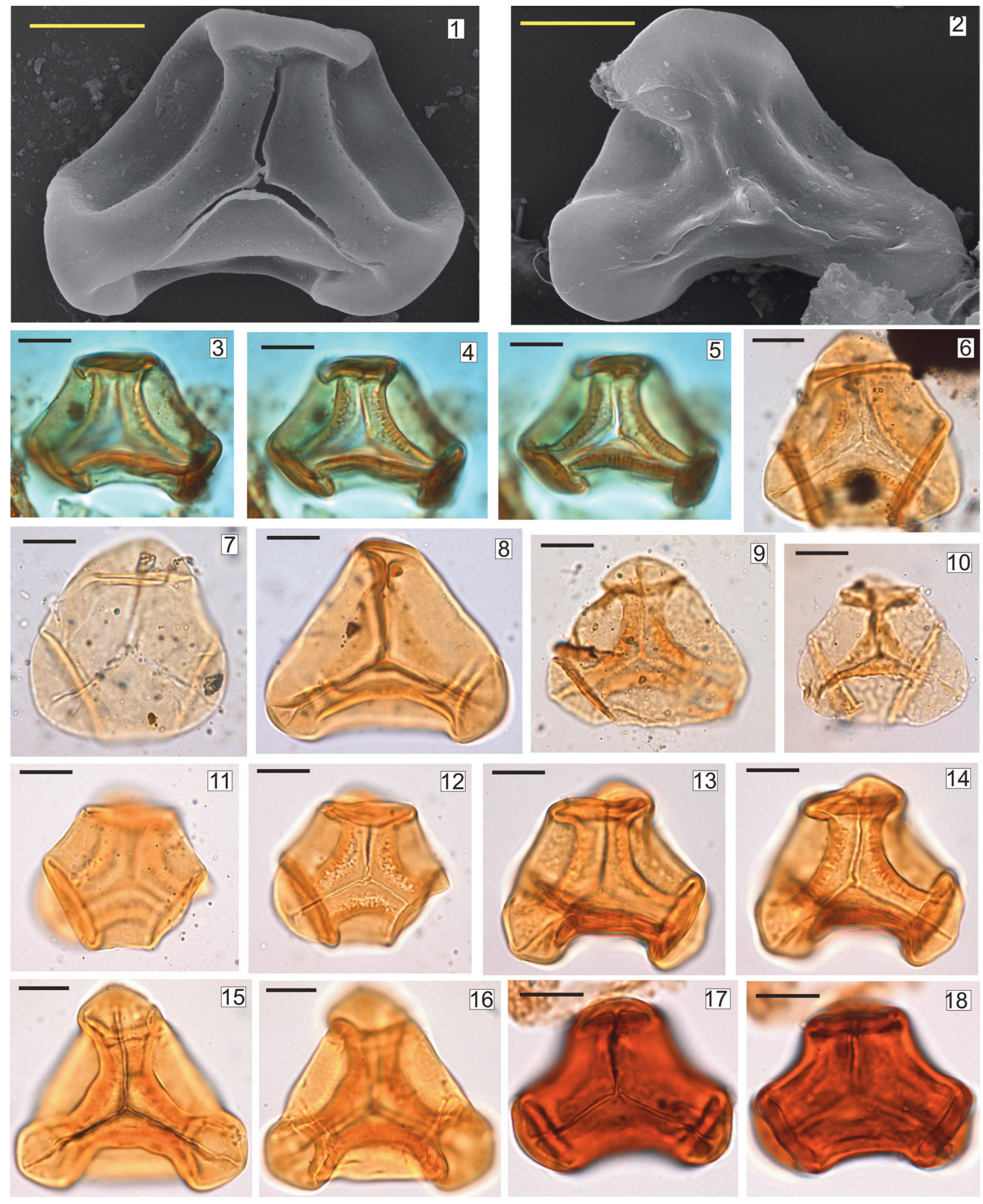

corrosion; Fig. 8 - C. jurienensis, LM photo NB38, slide 321-BMR1, EF T26/4. Obtusi apparatus reduced to a single distal fold; Fig. 9 - C. jurienensis, LM photo NF3, slide 336-BNG1, EF G48. Obtusi apparatus consisting of two folds; Fig. 10 - C. jurienensis, LM photo NF15, slide 336-BNG1, EF P30. Obtusi apparatus situated near the middle of the spore in contact with the small kyrtome; Figs. 11-12 - C. jurienensis, LM photos MJ10-11, slide 313-BMJ4, EF F54. Specimen with slightly concave sides and three distinct distal folds. Perforations at the central margin of the kyrtome are interpreted as preservational artefacts, probably the result of beginning degradation; Figs. 13-14 - C. jurienensis, LM photos NA21-22, slide 319-BMP2, EF G47. Distorted specimen with an invaginated (concave) lower side. Again, perforations at the margin of the kyrtome are interpreted as preservational artefacts; Figs. 15-16 - C. jurienensis, LM photos MZ56-57, slide 318-BMO2, EF Q42. Undistorted specimen with a triangular equatorial outline; Figs. 17-18 - C. jurienensis, LM photos MY26-27, slide 317-BMN1, EF U43/1. Specimen with concave sides or C. jurienensis sensu Singh, 1971. 

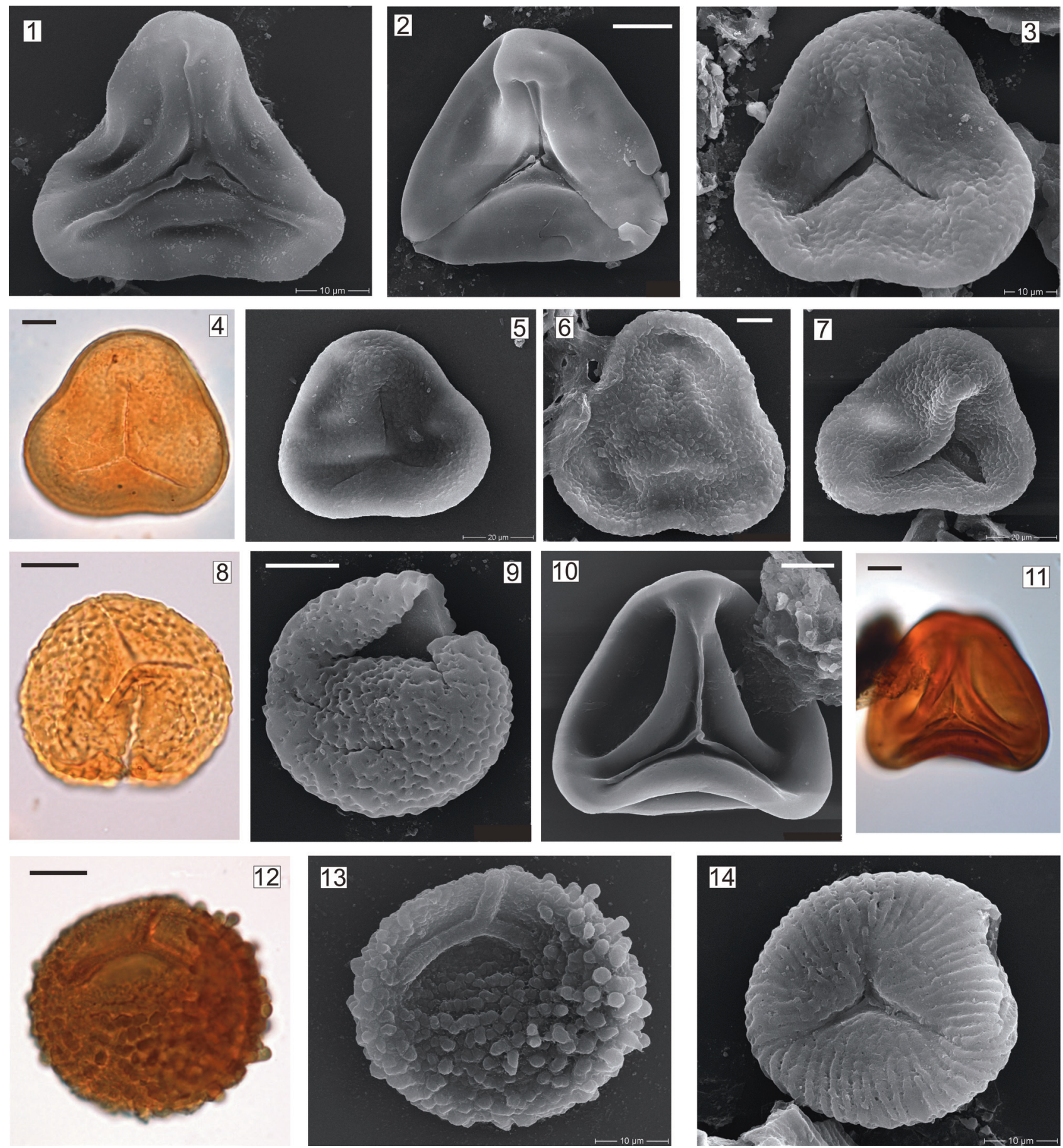

Plate 2. Some laevigate, granulate and cicatricose pteridophytic spores from the Albian of Makhtesh Qatan. Scale bar corresponds to $10 \mu \mathrm{m}$ unless otherwise indicated.

Fig. 1 - Dictyophyllidites cf. harrisii Couper sensu Volkheimer et al. (2007); SEM photo CJ13, specimen with slightly concave sides and distinct kyrtome, slide 327-BMX3; Fig. 2 - Dictvophyllidites harrisii, SEM photo CJ7, straight to slightly convex sides, indistinct kyrtome, slide 327-BMX3, Fig. 3 - Concavissimisporites punctatus, SEM photo CI12, slide 315-BML2; Fig. 4 - Concavissimisporites punctatus, LM photo NG81, slide 329-BMZ2, England Finder L40/4; Fig. 5 - Same specimen, SEM photo CJ 65; Fig. 6 Concavissimisporites cf. variverrucatus, distal view, SEM photo CJ10, slide 327-BMX3; Fig. 7 - Concavissimisporites cf. variverrucatus, proximal view, SEM photo CJ6, slide 327-BMX3; Fig. 8 - Osmundacidites sp. 1, LM photo MY43, slide 317-BMN2, England Finder W51/1, Fig. 9 - Osmundacidites sp. 1, SEM photo CI6, slide 315-BML2; Fig. 10 - Dictrophyllidites mesozoicus, SEM photo CJ51, slide 329-BMZ2; Fig. 11 - Same specimen, LM photo NG79, England Finder P41; Fig. 12 - Gemmatriletes clavatus, LM photo NH25, slide 329-BMZ7+8, England Finder H-J38; Fig. 13 - Same specimen, SEM photo CL52; Fig. 14 - Cicatricosisporites avnimelechi, SEM photo CJ 27, slide 327-BMX3. 


\section{LITERATURE CITED}

Abdelmalik, W.M., N.A. Aboul Ela \& A.G. El-Shamaa 1981. Upper Jurassic-Lower Cretaceous microflora from the North-Western Desert, Egypt. Neues Jahrbuch für Geologie und Paläontologie 162:244-263.

Backhouse, J. 1988. Late Jurassic and Early Cretaceous palynology of the Perth Basin, Western Australia. Geological Survey of Western Australia Bulletin 135:1-233.

Balme, B.E. 1957. Spores and pollen grains from the Mesozoic of Western Australia. Commonwealth Scientific and Industrial Research Organization, Reference T.C. 25:1-48.

Batten, D.J. \& P.J.R. Uwins 1985. Early-Late Cretaceous (Aptian-Cenomanian) palynomorphs. Journal of Micropalaeontology 4(1):151-168.

Brelie, G. von der 1964. Eine unterkretazische Mikroflora aus dem nördlichen Sauerland. Fortschritte in der Geologie von Rheinland und Westfalen 12:117-168.

Brenner, G.J. 1968. Middle Cretaceous spores and pollen from northeastern Peru. Pollen et Spores 10:341-383.

Brenner, G.J. 1974. Palynostratigraphy of the Lower Cretaceous Gevar'am and Talme Yafe formations in the Gevar'am 2 well. Geological Survey of Israel, Bulletin 59:1-27, 10 pls.

Brenner, G.J. \& I.S. Bickoff 1992. Palynology and age of the Lower Cretaceous basal Kurnub Group from the Coastal Plain to the northern Negev of Israel. Palynology 16:137-185

Burger, D. 1966. Palynology of uppermost Jurassic and lowermost Cretaceous strata in the eastern Netherlands. Leidse Geologische Mededelingen 35:209-276.

Couper, R.A. 1958. British Mesozoic microspores and pollen grains. A systematic and stratigraphic study. Palaeontographica Abt. B 103, Liefg. 4-6:75-179.

Dettmann, M.E. 1963. Upper Mesozoic microfloras from south-eastern Australia. Proceedings of the Royal Society of Victoria 77(1):1-148, 27 pls.

Diez, J.B., L.M. Sender, U. Villanueva-Amadoz, J. Ferrer \& C. Rubio 2005. New data regarding Weichselia reticulata: soral clusters and the spore developmental process. Review of Palaeobotany and Palynology 135:99-107.

Döring, H. 1965. Die sporenpaläontologische Gliederung des Wealden in Westmecklenburg (Struktur Werle). Geologie, Jahrgang 14, Beiheft 47:1-118.

El Beialy, S.Y., M.J. Head \& H.S. El Atfy 2010. Palynology of the Mid-Cretaceous Malha and Galala formations, Gebel El Minshera, North Sinai, Egypt. Palaios 25:517-526.

Filatoff, J. 1975. Jurassic palynology of the Perth Basin, Western Australia. Palaeontographica, Abt. B, 154:1-113.

Herngreen, G.F.W. 1973. Palynology of Albian-Cenomanian strata of borehole 1-QS-1-MA, state of Maranhao, Brazil. Pollen et Spores 15:515-555.

Horowitz, A. 1970. Jurassic microflora from the northern Negev, Israel. Israel Journal of Earth-Sciences 19:153-182.

Ibrahim, M.I.A., N.M. Aboul Ela \& S.E. Kholeif 2001. Palynostratigraphy of Jurassic to Lower Cretaceous sequences from the Eastern Desert of Egypt. Journal of African Earth Sciences 32:269-297.

Kedves, M. 1995. Upper Cretaceous spores from Egypt. Szeged, $87 \mathrm{pp}$.

Kedves, M. \& P. Simoncsics 1964. Microstratigraphy of the carbonate manganese ore layers of the shaft III of Úrkút on the basis of palynological investigations. Acta
Mineralogica-Petrographica S zeged 16(2):3-48.

Kotova, I.Z. 1990. Palynological complexes of the Lower Cretaceous of Syria. In: Paleofloristika i Stratigrafiya Phanerozoya, vypusk 2, pp. 85-101, Geologicheskii Institut AN SSSR, Moscow (in Russian). [Котова И.3. 1990. Палинокомплексы нижнего мела Сирии // Палеофлористика и стратиграфия фанерозоя. Москва: Геологический институт АН СССР. Вып. 2. С. 85-101].

Krassilov, V. \& E. Schrank 2011. New Albian macro- and palynoflora from the Negev (Israel) with description of a new gymnosperm morphotaxon. Cretaceous Research 32:13-29.

Krutzsch, W. 1959. Mikropaläontologische (sporenpaläontologische) Untersuchungen in der Braunkohle des Geiseltales. Geologie, Jahrgang 8, Beiheft 21-22:1-425.

Kumar, A. 1980. Palynostratigraphy and palaeoecology of the Navarro Group (Maestrichtian) of Texas, U.S.A. Proceedings IV International Palynological Conference, Lucknow (1976-77), 2:429-435.

Lewy, Z. 1981. A Late Albian Hypengonoceras (Ammonoidea) from the "Bentonite-Bed" at Makhtesh Ramon, Southern Israel. Israel Journal of Earth Sciences 30:35-38.

Mahmoud, M.S. \& A.S. Deaf 2007. Cretaceous palynology (spores, pollen and dinoflagellate cysts) of the Siqeifa 1-X borehole, northern Egypt. Rivista Italiana di Paleontologia e Stratigrafia 113:203-221.

Mego, N. \& M.B. Pramparo 2013. Esporas triletes verrucosas de la Formación Lagarcito (Albiano?), Sierra de Guayaguas, Provincia de San Juan, Argentina: Análisis bioestratigráfico. Revista Brasileira de Paleontologia 16(3):427-440.

Palynodata Datafile, 2005 Version. Created for Palynodata Inc. Halifax, Nova Scotia, Canada, by Blair Parsons, PalyEast.

Pons, D. 1988. Le Mésozö̈que de Colombie. Macroflores et microflores. Cahiers de Paléontologie. Éditions de Centre National de la Recherche Scientifique, Paris, 168 pp., 30 pls.

Pons, D., P.-Y. Berthou, J.B. de Melo Filgueira \& J.J. Alcantara Sampaio 1996. Palynologie des unités "Fundão", "Crato" et "Ipubi" (Aptien supérieur à Albien inférieur-moyen, bassin d'Araripe, nord-est du Brésil): enseignements paléoécologique, stratigraphiques and climatologique. Géologie de l'Afrique et de l'Atlantique Sud: Actes Colloques Angers 1994, 383-401.

Ravn, R.L. 1995. Miospores from the Muddy Sandstone (upper Albian), Wind River Basin, Wyoming, USA. Palaeontographica, Abt. B, 234 (Lfg. 3-6):41-91.

Regali, M.S.P. 1989. Evolução da paleoflora no Cretáceo das margens equatorial e nordeste do Brasil. Revista Escola de Minas 42(4):17-33.

Saad, S.I. \& G. Ghazaly 1976. Palynological studies in Nubia sandstone from Kharga Oasis. Pollen et Spores 18:407-470.

Schrank, E. 1994. Palynology of the Yesomma Formation in Northern Somalia: a study of pollen, spores and associated phytoplankton from the Late Cretaceous Palmae Province. Palaeontographica Abt. B 231:63-112.

Schrank, E. 2013. New taxa of winteraceous pollen from the Lower Cretaceous of Israel. Review of Palaeobotany and Palynology 195:19-25.

Schrank, E. \& M.I.A. Ibrahim 1995. Cretaceous (AptianMaastrichtian ) palynology of foraminifera-dated wells (KRM-1, AG-18) in northwestern Egypt. Berliner geowissenschaftliche Abhandlungen, Reihe A, 177:1-44.

Shaw, C.-L. \& T.-C. Huang 1994. Cretaceous palynomorphs of Taiwan (2) - taxonomic treatment. Taiwania 39:81-198.

Singh, C. 1971. Lower Cretaceous microfloras of the Peace River area, northwestern Alberta. Research Council of Alberta Bulletin 28, vol. 1:i-xi, 1-299, vol. 2:iii-vii, 301-542. 
Singh, C. 1983. Cenomanian microfloras of the Peace River area, northwestern Alberta. Alberta Research Council Bulletin 44:1-322.

Song Z., Shang Y., Liu Z., Huang P., Wang X., Qian L., Du B. \& Zhang D. 2000. Fossil Spores and Pollen of China, vol 2: Mesozoic Spores and Pollen, 710 pp., Science Press, Beijing (in Chinese with English summary).

Srivastava, S.K. 1977. Microspores from the Fredericksburg Group (Albian) of the southern United States. Paléobiologie continentale, 1975, 6(2):1-119, 48 pls.

Srivastava, S.K. 1987. Jurassic spore-pollen assemblages from Normandy (France) and Germany. Geobios 20(1):5-79.

Sultan, I.Z. 1986. Palynostratigraphy of Lower Cretaceous sediments in the Nile Delta region, Egypt. Revista Espanola de Micropaleontología 18:55-70.

Thusu, B. \& J.G.L.A. van der Eem 1985. Early Cretaceous (Neocomian-Cenomanian) palynomorphs. Journal of Mic- ropalaeontology 4:131-150.

Volkheimer, W., L. Scafati \& D.L. Melendi 2007. Palynology of a Danian warm climatic wetland in central Northern Patagonia, Argentina. Revista Española de Micropaleontología 39:117-134.

Voronova, M.A. 1984. Miospores of the Early Cretaceous of Ukraine. Naukova dumka, Kiev, 117 pp. (in Russian). [Boронова М.А. 1984. Миоспоры раннего мела Украины. Киев : Наукова Аумка. 117 с.].

Weissbrod, T., G. Gvirtzman \& B.H. Conway 1994. The Early Cretaceous sequence of the Sinaf 1 borehole (southern Negev) and its stratigraphic implications. GSI Current Research 9:67-72.

Wingate, F.H. 1980. Plant microfossils from the Denton Shale Member of the Bokchito Formation (Lower Cretaceous, Albian) in Southern Oklahoma. Oklahoma Geological Survey Bulletin 130:i-x, 1-94.

\section{Eckart Schrank:}

I do not remember the exact time when I first met Valentin Krassilov, but it must have been more than 25 years ago. In $1990 \mathrm{I}$ had the pleasure and the privilege to meet him, his wife Sophia Barinova and their daughter Katja on the occasion of the International Symposium Nonmarine Cretaceous Correlations (IGCP Project 245) in Alma-Ata. Valentin was editor of the Abstract volume, of the Program and Excursion Guide and he acted as one the coordinators of this great event, which included extended field trips and helicopter flights over the spectacular mountains of that region.

Many years later, in the meantime Valentin had moved to the University of Haifa, he suggested to me to propose a research project entitled "Fossil record of angiosperm advent, early evolution and paleoecology in the Middle East" to the German-Israeli Foundation for Scientific Research and Development (GIF). This proposal was finally successful and enabled us to do joint research between 2007 and 2010. For this experience I am grateful to Valentin and to GIF. 